\title{
INFLUENCE OF ALTITUDE IN THE DISTRIBUTION OF THE AQUATIC HYDROPHILOIDEA (COLEOPTERA) IN THE PROVINCE OF LEON (NW SPAIN)
}

\author{
L.F. valladares,' M.C. Fernández Aláez ${ }^{2}$ and M. Fernandez Aláez ${ }^{2}$ \\ 1. Departamento de Ciencias y Tecnología Agrarias. E. U. Politécnica Agraria. Universidad de Valladolid. 34071 \\ Palencia. Spain. \\ 2. Area de Ecología. Facultad de Biología. Universidad de León. Spain.
}

Keywords: Hydrophiloidea, altitudinal factor, distribution, NW Spain.

\begin{abstract}
An analysis of the influence of altitude is camed out by means of an analysis of the distribution of 101 species and subspecies reported from 278 sampling zones disposed throughout the province of León. After defining the species nchness in the different altitudinal levels we point out the indicator species by establishing their ecological features in terms of the reciprocal information species-factor. Affinity relationships between altitudinal levels are also analyzed.
\end{abstract}

\section{INTRODUCTION}

In many cases the altitude may determine the distribution of aquatic insects since this factor sets the gradient which influences several characteristics of the aquatic environment and therefore the associated fauna. Our aim here is to show the connexion between the distribution of the species of Hydrophiloidea (Hydraenidae and Hydrophilidae s.1.) collected in the province of León and the altitudinal factor by showing which species are strongly influenced by this factor.

Although no overall studies of this kind on this group have yet been carried out in other geographic areas, we may consider as a partial reference, the works on longitudinal zonation in fluvial courses of the species of genus Hydraena carried out by BinAGHi (1958, 1959, 1960, 1961 and 1965) in Italy and above all BERTHELEMY (1966) and TIBerghien (1976) in the Pyrennes.

Limnetica, 6: 79-86 (1990)

(C) Asociación Española de Limnología, Madrid, Spain

\section{MATERIAL AND METHODS}

The area studied is within the limits of the province of León, in the nortwest of the Iberian Peninsula (fig. 1). Most of the land consists of a range of different environment from the southern slopes of the Cantabrian mountains in the north to the Castilian Meseta in the south. It is also worth mentionin the mountainous zones in the west known as the Montes de León and the Cabrera mountains, as well as the lowland area known as the Bierzo.

The samples on which this work is based were collected mainly from 1983 to 1985 in 278 sampling zones ranging from different aquatic areas in León. These zones are widely distributed in the province and thus show as closely as possible the fauna composition of the different natural areas. The altitude ranges from 490 to $1,650 \mathrm{~m}$.

The collection method varied according to the biotope analyzed and the taxa required. Prospections through visual techniques of collecting aqua- 
tic entomo-fauna have been carried out both in stagnant and running waters. In the latter, special care has been taken in collecting the species from lotic and lentic waters, and those attached to moss and semi-emerged stones. The list of the 101 species and subspecies catalogued so far, as well as a detailed description of the sites and the sampling techniques can be found in VALLADARES (1988).

These 278 sampling zones have been classified according to their height above sea level, as shown in fig. 2A; $100 \mathrm{~m}$ gaps are given between $600 \mathrm{~m}$ and $1,650 \mathrm{~m}$, including in the extreme types the values below 600 and over $1,650 \mathrm{~m}$. So, the number of intervals for the altitude factor is 11 .

The quality of the sampling has been measured by means of a comparison of the highest entropy $\left(\mathrm{H}[\mathrm{L} / \mathrm{max}]=\log _{2} \mathrm{NK}\right)$ with that resulting from the sarnpling actually carried out. The entropy linked with the altitudinal gradient has been calculated using the formula given by DAGET et al. (1972):

$$
H(L)=\sum_{1}^{N k} \frac{R(k)}{N R} \log _{2} \frac{N R}{R(k)},
$$

where $\mathrm{R}(\mathrm{k})=$ number of sampling zones for each altitudinal level, $\mathrm{NR}=$ total number of sampling zones, $\mathbf{N}(\mathrm{k})=$ number of altitudinal levels dealt with.

In the matrix of data defined by the frequency with which the 101 species are present in all 11 altitudinal levels, the corrected frequency of absolute values has been calculated by using the $\mathrm{DA}_{\mathrm{A}}$ GET \& GODRON (1982) formula:

$$
\mathrm{C}(\mathrm{k})=\frac{\mathrm{U}(\mathrm{k})}{\mathrm{R}(\mathrm{k})}: \frac{\mathrm{U}(\mathrm{E})}{\mathrm{NR}}
$$

where $U(E)=$ total number of zones in which species $\mathrm{E}$ is present, and $\mathrm{U}(\mathrm{k})=$ number of sampling zones for eath altitudinal level in which species $\mathrm{E}$ is present.

«Mutual information» between a species and a describer has been used as an indicator of the species rather than the altitude. For a species $E$ and a describer $\mathrm{L}, \hat{\mathbf{I}}$ stands for $(\mathrm{L} ; \mathrm{E})$ and is defined as follows (Godron, 1968):

$$
\begin{aligned}
& I(L ; E)=\sum_{1}^{N k} \quad \frac{U(k)}{N(R)} \quad \log _{2} \quad \frac{U(k)}{R(k)} \cdot \frac{N R}{U(E)}+ \\
& +\sum_{1}^{N k} \frac{V(k)}{N R} \log _{2} \frac{V(k)}{R(k)} \cdot \frac{N R}{V(E)}
\end{aligned}
$$

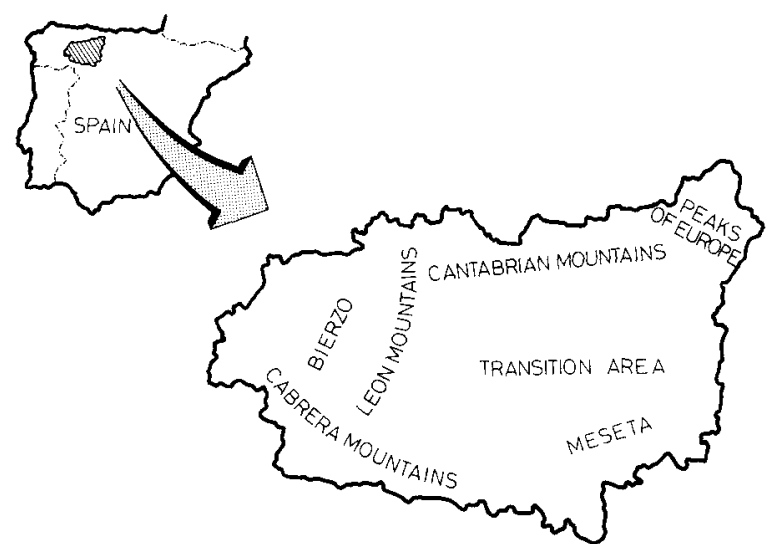

Figure 1.- Province of Leon: situation and natural areas Provincia de León: situación y áreas naturales.

where, besides the notation above, $\mathrm{V}(\mathrm{k})=$ total number of sarnpling zones for each altitudinal level in which species $\mathrm{E}$ is not present; $\mathrm{V}(\mathrm{E})=$ total number of sampling zones in which species $\mathrm{E}$ is not present.

\section{RESULTS}

The value obtained from the information linked with the altitudinal gradient was 3.04 bits. On the other hand, the highest entropy in the sampling, regarding only the number of altitudinal levels, was 3.46 bits, which lead to a sampling quality of 0.88 . Therefore, altitude is an efficient factor. The small loss of information is easily accounted for simply by taking into account the high frequency of sampling zones situated between 800 and $1,000 \mathrm{~m}$ $(57.55 \%)$, specially those present in the intervals $800-900,26.62 \%$ of the total (fig. 2A). A high percentage of the area of the province is within this range. So, although a distribution of the various altitudinal levels in percentages is not available, we know that $47.31 \%$ of the whole area is between 600 and $1,000 \mathrm{~m}$. In figure $2 \mathrm{~B}$ the distribution of the richness between the different altitudinal levels is represented. The zones which are richest in species are those between 700 and $1,100 \mathrm{~m}$. This distribution provides a high number of zones prospected in the different altitudinal levels (fig. 2), from which we can assume that the most 

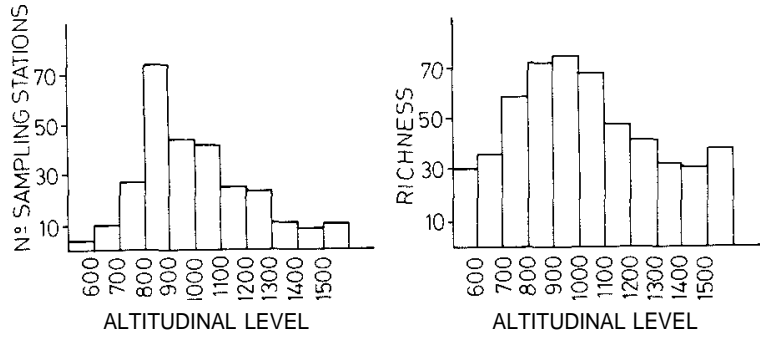

Figure 2.- Relationship between the sampling zones (A) and the nchness (B) for each of the altitudinal levels here dealt with.

Relación entre el número de estaciones de muestreo (A) y la riqueza específica (B) para cada uno de los niveles altitudinales considerados.

intensively sampled levels are richest in species. Nevertheless, although between 800-900 $\mathrm{m}$ the number of samplings yields a high percentage, such disproportion does not come out in the distribution of richness values, since the number of species in all three levels between 800 and $1,100 \mathrm{~m}$ are similar to each other.

\section{Indicative species in relation to altitude}

We estimated the information provided by each of the 101 species by calculating the values relating to $\hat{\mathbf{I}}(\mathrm{L} ; \mathrm{E})$. In this way, the indicator species have been identified and classified according to a scale of values. Only those whose mutual information species-factor was higher than 0.05 have been recorded in table 1 .

In fig. 3 the ecological features of corrected frequencies for those species whose indicative value is higher than 0.1 or very close to that are shown. By using corrected rather than absolute frequencies we try to solve, on the one hand, the problems of lack of information in the distribution of study areas among the different types of describer, and, on the other hand, the problem of deviations between features of abundant and nonabundant species.

The 17 species represented can be divided into groups according to their ecological features: (a) species with a wide altitudinal range, (b) those of upper reaches and (c) those of middle and lower reaches. a) Species with a wide altitudinal range

A commentary of the ecological features for each of the 10 species included in this group is as follows:

Hydraena (Hydraena) brachymera D'Orchymont, 1936 (fig. 3A): This is a typical mountain species, since it is not found below $700 \mathrm{~m}$, and is more abundant over $900 \mathrm{~m}$. Nevertheless, its optimal altitude level is just down stream from the source, although it is also present in this zone.

Hydraena (Haenydra) emarginata Rey, 1855 (fig. 3B): This species has a wide altitudinal range but it has been reported mainly in higher reaches. It is abundant over $1,100 \mathrm{~m}$ and it does not decrease in higher levels $(1,600 \mathrm{~m})$. It is not present in middle levels, and appears again in the lowest levels, basically in the Bierzo zone, rich in running waters.

Hydraena (Haenydra) exasperata D'Orchymont, 1935 (fig. 3C): Like all species of Haeny$d r a$ it shows a preference for the higher levels, although less than Hydraena emarginata, since it is rare over $1,300 \mathrm{~m}$ but it is abundant around the $1,000 \mathrm{~m}$ level. Its feature is quite parallel to that of $\boldsymbol{H}$. emarginata. This Iberian endemism is located in the intermediate ecological position of $\boldsymbol{H}$. (Haenydra) saga D'Orchymont in the Pyrenees between $\mathrm{H}$. emarginata and $\boldsymbol{H}$. gracilis (BERTHELEMY, 1966).

Hydraena (Haenydra) gracilis Germar, 1823 (fig. 3D): This Haenydra is absent in the Bierzo and is reported only in the Duero basin, but can also be detected in slightly higher levels $(1,000 \mathrm{~m})$, and decreases at higher levels. Its absence in the Bierzo zone means that captures under $700 \mathrm{~m}$ have not been reported.

Hydraena (Haenydra) truncata Rey, 1885 (fig. 3E): Basically it shares features with other Haenydra such as H. emarginata or $H$. exasperata, and is found preferentially between levels where these two species mostly appeared. These data coincide with those already compiled from the Pyrenees for this species (BERTHELEMY op. cit.). This species is very frequently reported at the bottom of Picos de Europa valleys.

Limnebius (Limnebius) truncatellus (Thunberg, 1794) (fig. 3F): It can be found in a wide range of levels from higher than $1,000 \mathrm{~m}$ to lower than $700 \mathrm{~m}$, mainly in mountain reaches, where it occupies the lentic waters of river banks. As with 
Table 1.- Species whose value for mutual information species-factor is higher than 0.05 . The asterisk indicates values higher than 0.1 .

Especies cuya información mútua especie-factor supera el valor 0,05. El asterisco indica valores superiores a 0,1 .

\begin{tabular}{|c|c|c|c|}
\hline Especies & Factor 1 & Especies & Factor I \\
\hline${ }^{*}$ Hydraena affusa & 0.121 & ${ }^{*}$ Helophorus brevipalpis & 0.138 \\
\hline${ }^{*} H$. brachymera & 0.118 & H. maritimus & 0.091 \\
\hline H. corrugis & 0.158 & $H \cdot$ glacialis & 0.082 \\
\hline H. inapicipalpis & 0.052 & H. minutus & 0.071 \\
\hline H. stussineri & 0.082 & ${ }^{*} H$. discrepans & 0.110 \\
\hline H. minutissima & 0.060 & ${ }^{*} H$. griseus & 0.124 \\
\hline *H. emarginata & 0.277 & *H. flavipes & 0.140 \\
\hline${ }^{*} H$. exasperara & 0.127 & H. seidlitzii & 0.063 \\
\hline${ }^{*} H$. gracilis & 0.116 & Anacaena globulus & 0.079 \\
\hline H. truncata & 0.090 & ${ }^{*}$ Berosus affinis & 0.173 \\
\hline Ochthebius exsculptus & 0.064 & ${ }^{*}$ Helochares lividus & 0.144 \\
\hline 0. legionensis & 0.078 & Hydrophilus pistaceus & 0.098 \\
\hline Limnebius lusitanus & 0.053 & Laccobius sinuatus & 0.080 \\
\hline L. maurus & 0.064 & L. striatulus & 0.053 \\
\hline L. truncatellus & 0.092 & L. obscuratus & 0.080 \\
\hline \multirow[t]{2}{*}{${ }^{*}$ Helophorus alternans } & 0.145 & L. atrocephalus ytenensis & 0.052 \\
\hline & & L. atratus & 0.069 \\
\hline
\end{tabular}

Hydraena this gradient is due to the situation of the aquatic sites in which this species is found.

Helophorus (Trichelophorus) alternans Gené, 1836 (fig. 3G): It spans the whole altitudinal gradient, except for the lowest levels. Although it is present in the higher levels, it can sometimes be found in areas of Transition and Meseta and is an abundant species between 700 and $1,000 \mathrm{~m}$.

Helophorus (Atracthelophorus) brevipalpis Bedel, 1811 (fig. $3 \mathrm{H}$ ): It is notably present in the lower levels of the province, rare in higher levels and not reported above $1,400 \mathrm{~m}$. It shows a prefference for hills and plains between 700 and $1,000 \mathrm{~m}$.

Helophorus (Helophorus) flavipes Fabricius, 1972 (fig. 31): This species has a wide altitudinal gradient and a low presence in the $700-900 \mathrm{~m}$ interval because it is widely spread throughout the province, and absent from the Meseta zone. It usually lives on the banks of fast flowing rivers, its presence being stronger in altitudes above $1,200 \mathrm{~m}$ or under $600 \mathrm{~m}$.

Helochares lividus (Forster, 1771) (fig. 3J): Its wide altitudinal gradient equals that of its distribution in the province. On the other hand, it is more frequent in lower levels, in general below $1,100 \mathrm{~m}$, and especially in this characteristic habitat: stagnant waters. b) Highland species

This group comprises three species which are typical of mountain reaches. The first is clearly rheophilic, and the other two live in the lenitic waters of the rivers, the latter being a typical glacial relic.

Hydraena (Hydraena) affusa D'Orchymont, 1936 (fig. 3K): It lives in the lotic waters of the crenon and rhithron of the Cantabrian courses in the Duero basin: it is not, therefore, present in levels lower than 600 or $700 \mathrm{~m}$, whereas other species of Hydraena are. This species lives mainly in 1,100 and $1,400 \mathrm{~m}$. Possible discontinuities in its features are due to the sampling.

Helophorus (Helophorus) discrepans Rey, 1885 (fig. 3L): This species is significantly more frequent in highlands, increasing from $800 \mathrm{~m}$ to more than $1,500 \mathrm{~m}$. It is a frequent element in the river banks of high mountain reaches.

Helophorus (Atracthelophorus) glacialis Villa, 1833 (fig. 3M): This is a borealpine species, relic from a glacial age in some European massifs (ANGUS, 1973, 1987). This is the reason why it is only found in the upper reaches of mountain passes. The corrected frequencies for the two upper altitudinal levels in which this species is present are very high, their values being 0.94 for $1,000 \mathrm{~m}$, 
14.44 for $1,300 \mathrm{~m}$ and 7.94 for levels higher than $1,500 \mathrm{~m}$. For this reason the ends have been darkened in the figure.

c) Lower and midland species

All four species of this group live in stagnant waters.

Helophorus (Helophorus) griseus Herbst, 1793 (fig. $3 \mathrm{~N}$ ): Although it can be found in high land, this species shows a preference for 700 and $1,100 \mathrm{~m}$ levels. The flat lands in which it lives are situated in this interval.

Berosus affinis Brullé, 1835 (fig. 30): Its features are similar to those of the former species. It lives in stagnant waters, mainly pools and ponds, and is particularly abundant in $800 \mathrm{~m}$ levels.

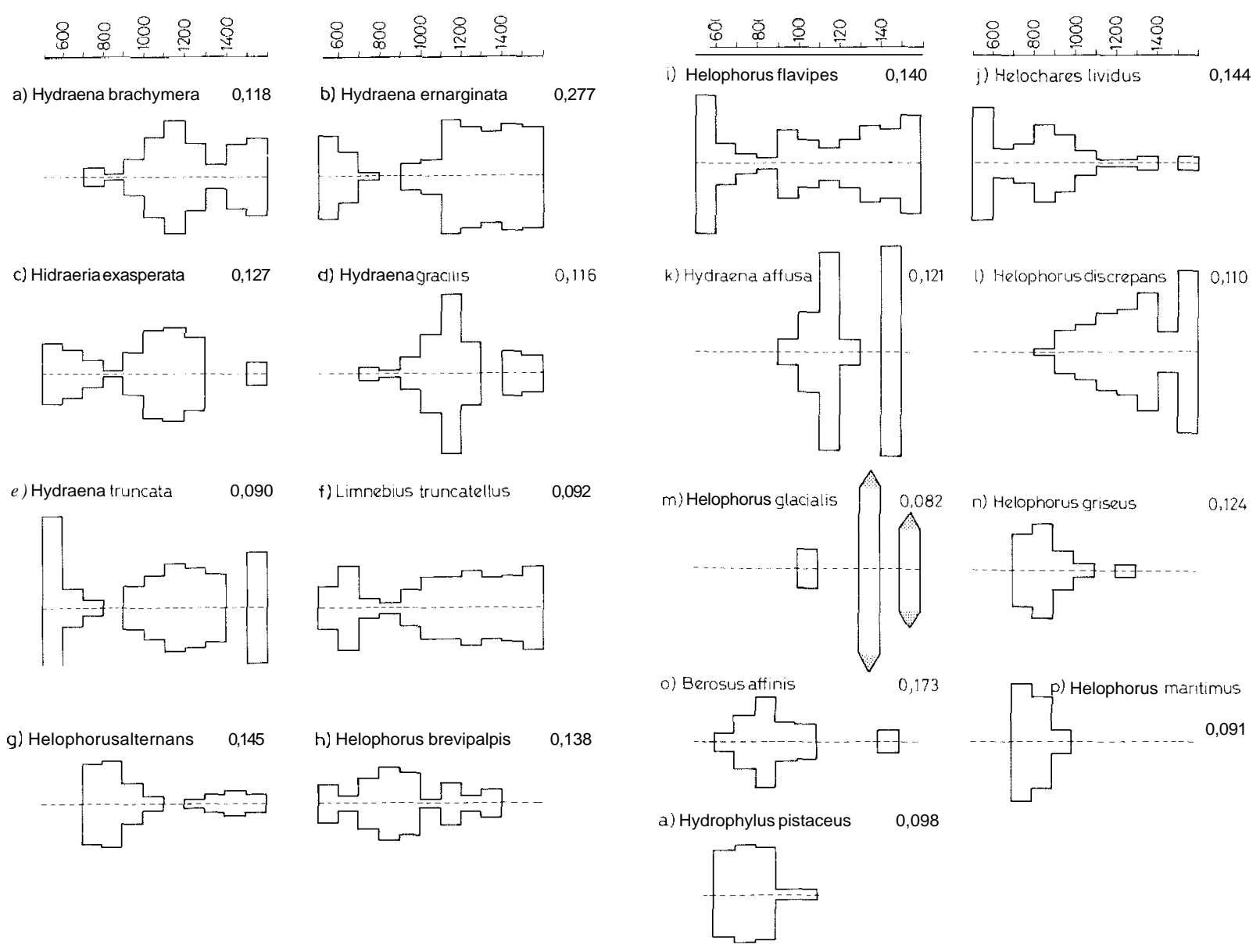

Helophorus (Meghelophorus) maritimus Rey, 1885 (fig. 3P): This is a typical flatland species, only present in levels between 700 and $1,000 \mathrm{~m}$, increasing its presence towards the lowland.

Hydrophilus pistaceus (Casterlnau, 1840) (fig. 3Q): It can be found in rather deep puddles rich in vegetation, being rare in mountainous areas of the province. It is characteristic of lowland areas.

d) Faunistic affinity between altitudinal levels

Finally the affinity relationship between the various altitudinal levels has been studied using the MотYKa et al. (1950) coefficient:

$$
S=\frac{2 W}{A+B} \cdot 100
$$

Figure 3.- Ecological features of corrected frequencies for those species that provide the most mutual information in relation to the altitudinal factor.

Perfiles ecológicos de frecuencias corregidas de las especies que aportan mayor información mútua con respecto al factor altitud. 
where $\mathrm{A}=$ the sum of quantitative values of all species in altitudinal level $\mathrm{A}, \mathrm{B}=$ the sum of quantitative values of all species in altitudinal level $\mathrm{B}$, and $\mathrm{W}=$ the sum of minimal quantitative values shared by the different altitudinal levels.

Two separate large groups of altitudinal levels can be seen in the affinity dendrograme (fig. 4). On the one hand levels between 700 and 1,300 m are differentiated, and on the other hand, extreme levels.

As for the former group, there is a clear distinction between provincial zones in the $700-900 \mathrm{~m}$ gap (corresponding to the Transition and Meseta species) and those in the 900-1,300 m gap, typical of higher mountain areas. In the second group, which includes very different levels, two subgroups are clearly differentiated which, on the one hand, include heights below $700 \mathrm{~m}$, and on the other hand, heights above 1,300 m.

\section{DISCUSSION}

The study of the influence of altitude on the distribution of aquatic palpicorns, based on inten- sive sampling over fairly wide surface area, makes it possible to establish the existence of indicator species which have been divided into three grups. Of the 10 species included in the group characterized by a large height amplitude, 5 are Hydraenidae typical of mountain water flows. They are present in low level areas, such as the Bierzo or the bottom of the Picos de Europa valleys, which have un abrupt relief with similar characteristics to high level mountain areas. This is the case of $H y d r a e n a$ emarginata, $H$. exasperata or $H$. truncata.

The rest of the species live in the lentic phase both in current and stagnant waters, and they are well distributed throughout the province, and localized on all altitudinal gradients. Species with this kind of distribution are Limnebius truncatellus, Helophorus flavipes or Helochares lividus. This last species has a clear tendency to live in lower areas. In all three cases they are species of high ecological variability under environmental factors which make up lentic habitats.

The scarce indicator species which are distributed in higher areas commonly tend to live in running waters, whether in rheophilic habitats, e.g. Hydraena affusa, or in the lentic waters in these mountain environments, e.g. Helophorus discre-
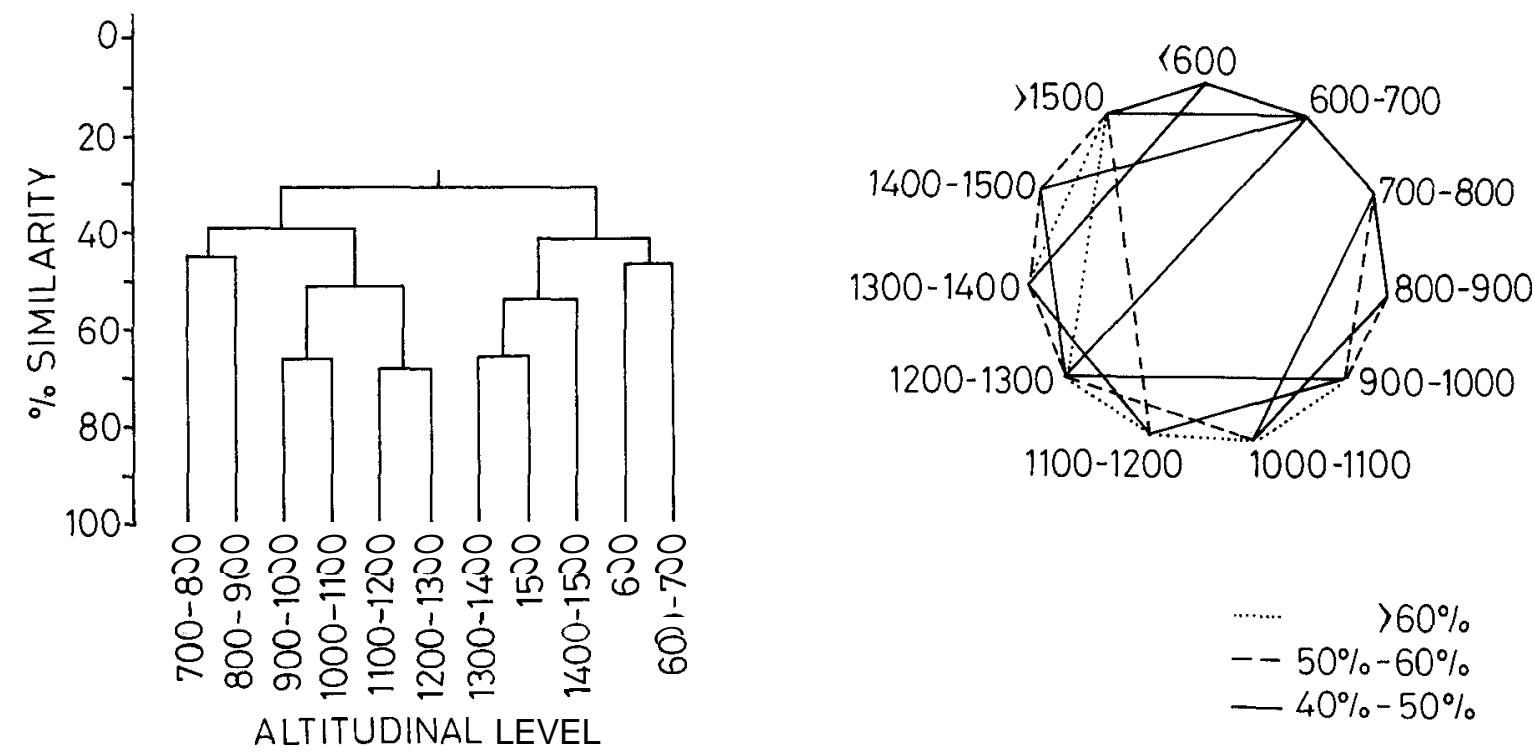

Figure 4.- Dendrogramme showing the affinity between the altitudinal levels here dealt with and graphic representation of the matrix of similitude.

Dendrograma de afinidad entre los niveles altitudinales considerados y representación gráfica de la matriz de similitud. 
pans or $\boldsymbol{H}$. glacialis, this last one being a typical glacial relic.

With regard to the indicator species at low level areas, the fact that they are characteristic elements of stagnant waters, such as pools and ponds situated at heights lower than $1,000 \mathrm{~m}$ above sea level, stands out. Helophorus maritimus or Hydrophilus pistaceus show a typical feature of a species at low altitudes, with their presence decreasing above $900 \mathrm{~m}$. The distribution of these species is associated with the environmental characteristics of the lentic ecosystems in the flatland with an obvious mediterraneam influence which impedes their presence in stagnant waters in mountainous areas.

With relation to the study of the faunistic affinity between different altitudinal levels, the formation of a group defined in a similarity level somewhat higher than $40 \%$ and comprising very different altitudinal levels stands out. This group may have formed because of the presence of running water species found in extreme altitudinal levels.

An overall view of the results obtained shows the distinct influence of the height factor on the distribution of the species depending on whether they occupy lotic or lentic environments. In this way, in the rheophilic species, altitude does not seem to be a decisive factor, and in the majority of them, such as the representatives of the Hydraena genus, variables such as slope, grade size or riverbed and the nature of substratum, may have a greater influence. On the other hand, in the species of lentic environments, altitude increases its importance as a determining factor.

\section{ACKNOWLEDGEMENTS}

Many thanks to Joaquín Conde Moreno for translating the Spanish manuscript.

\section{RESUMEN}

\section{INFLUENCIA DE LA ALTITUD EN LA DISTRIBUCIÓN DE LOS HYDROPHILOIDEA (COLEÓPTEROS) ACUÁTICOS EN LA PROVINCIA DE LEÓN (NW ESPAÑA)}

En base a la distribución de presencias de las 101 especies y subespecies de palpicornios (Coleoptera Hydrophiloidea) detectadas en 278 estaciones de muestreo repartidas por toda la provincia de León, se efectúa un análisis de la influencia del factor altitud. Después de definir el comportamiento de la riqueza específica en los distintos niveles altitudinales se señalan las especies indicadoras, estableciendo sus perfiles ecológicos en función de la información mútua especie-factor. Se analizan igualmente las relaciones de afinidad entre niveles altitudinales.

\section{BibLiogRAPHY}

Angus, R.B., 1973. Pleistocene Helophorus (Coleoptera, Hydrophilidae) from Borislav and Starunia in the Western Ukraine, with a reinterpretation of U. Lomnicki's species, description of a new Siberian species, and comparison with British Weichselian faunas. Phil. Trans. R. Soc. London (B) 265: 299-326.

ANGUS, R.B., 1987. A revision of the species of Helophorus Fabricius, subgenus Atracthelophorus Kuwert, ocurnng in France, the Iberian Peninsula and North Afnca, with a note on $\boldsymbol{H}$. discrepans Rey in Morocco (Coleoptera, Hydrophilidae). Nouv. Revue Ent. (N.S.) 4(1): 45-60.
BERTHELEMY, C., 1966. Recherches écologiques et biogeographiques sur les Plécoptkres et Coléoptkres d'eau courante (Hydraena et Elminthidae) des Pyrénées. Annls. Limnol. 2: 224-458.

BinagHI, G., 1958. Materiali per lo studio delle Hydraena italiane (1. ${ }^{a}$ Contributo). Bol. Soc. ent. Ital. 88: 70-83.

Binaghi, G., 1959. Materiali per lo studio delle Hydraena italiane (2. ${ }^{a}$ Contnbuto). Bol. Soc. ent. Ital. 89: 68-84.

BinAGHI, G., 1960. Materiali per lo studio delle Hydraena italiane et notizie su alcune specie della coleotterofauna aequatica viventi in associazione (3. ${ }^{a}$ Contributo). Bol. Soc. ent. Ital. 90: 15-41. 
BiNAGHI, G., 1961. Materiali per lo studio della Hydraena italiane. Le Hydraena dell'Isole d'Elba e notizie sulla coleotterofauna aequatica associata $\left(4 .{ }^{a}\right.$ Contnbuto). Bol. Soc. ent. Ital. 91: 66-77.

Binaghi, G., 1965. Matenali per lo studio della Hydraena italiane (6. ${ }^{\circ}$ Contributo). Mem. Soc. ent. Ital. 44: 12-22.

Daget, P., M. Godron \& J.L. Guillerm, 1972. Profils écologiques et information mutuelle entre éspkces et facteures écologiques. In: Grundfragen un Methoden in der Pflanzensoziologie: 121-149. Junk Publ. La Haya.

Daget, P. \& M. Godron, 1982. Analyse de l'Écologie des espèces dans les communautés. Coll. d'Ecologie. Masson, $\mathrm{Pa}-$ rís, $163 \mathrm{pp}$.
GoDron, M., 1968. Quelques aplications de la notion de frécuence en écologie végétale (recouvrement, information mutuelle entre éspkces et facteurs écologiques, échantilonnage). Oecol. Plant. 3: 185-212.

Motyka, J., B. Dobrzansky \& S. Zawadzky. 1950. Wstepne badania rad lakami poludniowo voschodniej Lubelszczyzny. Ann. Univ. Marie Curie Sklodowska (Sect. E Agricultura) 5: 367-447.

Tiberghien, G., 1976. Écologie des Helodidae, Elminthidae et Hydraenidae d'un cours d'eau des Pyrénées atlantiques: Le Lissurage. Thése. Univ. P. Sabatier de Toulouse, T. 1: 444 pp. T. 2: 102 figs.

VAlladares, L.F., 1988. Los Palpicornios acuáticos de la provincia de León (Coleoptera, Hydrophiloidea). Secretariado de Publicaciones. Universidad de León. 38 pp. 